\author{
Marcin Pleśniak* \\ ORCID: 0000-0002-3024-2735 \\ Uniwersytet Wrocławski
}

DOI: $10.19195 / 1733-5779.26 .8$

\title{
Fundacja jako forma aktywizacji osób niepełnosprawnych i starszych
}

JEL Classification: K23

Słowa kluczowe: fundacja, osoby niepełnosprawne, osoby starsze, działalność gospodarcza, stowarzyszenia

Keywords: foundation, disabled people, seniors, economic activity, association

Abstrakt: Niniejszy artykuł ma na celu zaprezentowanie fundacji, które oprócz stowarzyszeń są najpopularniejszą formą działalności społecznej jako środka aktywizacji dwóch zagrożonych wykluczeniem grup społecznych, czyli osób niepełnosprawnych i starszych. Po krótkim rysie historycznym kształtowania się fundacji jako podmiotu prawa została zaprezentowana konstrukcja prawna owego podmiotu. Ustawową podstawą funkcjonowania fundacji w Polsce jest ustawa z 1984 roku o fundacjach. Ponadto w artykule zestawiono cechy fundacji i stowarzyszenia, które są dwiema najpopularniejszymi formami działalności społecznej. Najważniejsze różnice między nimi to:

1. Istota: fundacje - istotą jest majątek przekazywany przez fundatora; stowarzyszenia istotą jest grupa osób tworząca zrzeszenie;

2. Organy: fundacje — jedyny obligatoryjny organ stanowi zarząd, inne organy są fakultatywne; stowarzyszenia - organy obligatoryjne to zarząd i organ kontroli wewnętrznej, walne zebranie członków jako najwyższa władza w stowarzyszeniu;

3. Cele/Działania: fundacje - realizacja celów statutowych zgodnych z podstawowymi interesami Rzeczypospolitej Polskiej, niedopuszczalne działania na rzecz członków władz fundacji; stowarzyszenia — możliwe działania na rzecz członków stowarzyszenia oraz podmiotów zewnętrznych.

W artykule opisano pojęcie działalności gospodarczej i możliwości podejmowania działalności gospodarczej przez fundacje. Scharakteryzowano również doświadczenia autora związane $\mathrm{z}$ uczestnictwem w działalności fundacji. Według autora głównymi problemami nowych fundacji są niejasne kryteria rozstrzygania konkursów o realizację zadań publicznych organizowanych

* Opiekun naukowy (Scientific Tutor) — Tadeusz Kocowski

Studenckie Prace Prawnicze, Administratywistyczne i Ekonomiczne 26

Studenckie Prace Prawnicze, Administratywistyczne i Ekonomiczne 26, 2018

(C) for this edition by CNS 
przez władze publiczne, a także trudności z pozyskiwaniem środków finansowych przed uzyskaniem statusu organizacji pożytku publicznego. Ukazano problemy nowych, rozpoczynających działalność fundacji. Wskazano obszary działalności fundacji pomagających osobom niepełnosprawnym i starszym. Są nimi przede wszystkim opieka i wsparcie w opiece nad seniorami i osobami niepełnosprawnymi, jak również organizowanie dostępu do kultury i sztuki, a także organizowanie wyjazdów turystycznych dla tych grup społecznych.

\section{The foundation as the form activation of the of disabled and elderly persons}

Abstract: The purpose of this article is to describe foundations, which are one of the most popular form of social activities next to associations. The author presents the foundation as a good way to the mobilization of disabled and elderly people. In the first part of the article the author presents a brief history of the development of foundations. The next section presents legal grounds of foundation in the Polish law. This ground is the Law of Foundation, dated 1984. Additionally, the article presents a comparison of the two forms of the social activities: foundations and associations. The most important differences are:

Foundations - the main component of it are assets donated by the sponsor. Associations people who create this form of social activity are the main component.

Foundations - governing board holds the control over foundations; other organs are optional. Associations - authorities comprise of assembly of association members, governing board and an obligatory internal audit office.

Foundation - directs its activities and represents it to the world; cannot direct its activities to the governing board. Associations - activities can be directed to the world but also to the members of the association.

The article also presents a definition of economic activity and foundations' possibilities to take such activities. The author describes his own experience at the foundation created by teachers and graduates from his former school for blind children.

The article presents common challenges newly starting foundations have to face, the most important of which is the problem of vague evaluation criteria for applications in competitions organized by public authorities and problems with acquiring source of funds for their activity.

In the last part of the article the author presented areas of activities performed by foundations working for disabled and elderly persons. The main scope is, of course, taking care of the elderly and disabled, but also facilitating the access to culture, art and the organization of tourist trips.

The above mentioned activities are more and more needed and a lot of organizations are developing these areas.

\section{Wstęp}

W niniejszym artykule autor przedstawi konstrukcję prawną jednego z najważniejszych podmiotów z obszaru tak zwanego trzeciego sektora, jakim jest fundacja. Zostaną ukazane zalety tej formy działalności w procesie aktywizacji osób niepełnosprawnych i starszych. $Z$ racji doświadczeń autora w tym obszarze zostaną ukazane problemy, z jakimi borykają się nowo zakładane fundacje. Zdaniem autora ważne jest ukazanie możliwości działalności fundacji, również w sferze gospodarczej. Ukazane zostaną podstawowe różnice pomiędzy fundacją a stowarzyszeniem. 
W artykule wykorzystana zostanie metoda badawcza formalno-dogmatyczna. Wykorzystano literaturę przedmiotu oraz doświadczenie autora zdobyte w trakcie uczestnictwa w procesie zakładania, rejestracji i prowadzenia fundacji.

\section{Rys historyczny}

Początki fundacji sięgają czasów rzymskich. W okresie późnego cesarstwa rzymskiego, w okresie chrześcijańskim wyróżniano masy majątkowe specjalnie wyodrębnione i przekazywane gminom, stowarzyszeniom bądź osobom prywatnym z przeznaczeniem na określone cele (na przykład utrzymywanie sierot) nazywane fundacjami niesamodzielnymi ${ }^{1}$. $\mathrm{Z}$ czasem (około V-VI wieku n.e.) wyodrębniły się osoby prawne, fundacje samodzielne z własnymi organami zarządzającymi. Dużą rolę odegrał Kościół tworzący w takiej formie swoje klasztory i świątynie ${ }^{2}$. Okres średniowiecza to przewaga fundacji o charakterze kościelnym. Klaruje się wówczas definicja fundacji, która przetrwała do dziś. Jak wskazują B. Sagan, J. Strzępka w Prawie o fundacjach, za fundację uważano majątek przeznaczony $\mathrm{z}$ woli fundatora na cel określony w akcie fundacyjnym ${ }^{3}$. Kościół prowadził w tej formie prawnej rozległą działalność charytatywną. Fundowano wiele przytułków przyparafialnych i przykatedralnych pomagających ubogim, co było zgodne z chrześcijańską doktryną miłosierdzia i jałmużny wobec nich. O ile w średniowieczu fundatorami/donatorami Kościoła byli raczej władcy, o tyle w późniejszych wiekach rolę tę przejmują rody możnowładcze i rozwijają się fundacje świeckie. Powstają również fundacje uniwersyteckie, dla przykładu warto wymienić powołane przez Kazimierza Wielkiego Zrzeszenie uczących się ${ }^{4}$. Okres zaborów to czas powstawania i funkcjonowania zasłużonych dla polskiej kultury fundacji. Najsłynniejszą i działającą do dzisiaj we Wrocławiu jest Zakład Narodowy im. Ossolińskich ustanowiony w 1817 roku, na podstawie austriackiego prawa fundacyjnego ${ }^{5}$. W Polsce międzywojennej fundacje prawa prywatnego tworzono na podstawie przepisów prawnych państw zaborczych. Jedynie w byłym zaborze rosyjskim obowiązywał dekret Naczelnika Państwa z dnia 7 lutego 1919 roku o fundacjach i zatwierdzaniu darowizn i zapisów ${ }^{6}$. Innym zagadnieniem były fundacje prawa publicznego powoływane na mocy odrębnych ustaw ${ }^{7}$. Wśród fundacji publicznych wyróżniano dwa typy: pierwszy to fundacje państwowe, tworzone w drodze ustawy przez państwo, wydzielające ze swoich zasobów określony sub-

1 K. Kolańczyk, Prawo rzymskie, Warszawa 2000, s. 247.

2 Ibidem, s. 247.

3 B. Sagan, J. Strzępka, Prawo o fundacjach. Komentarz, Katowice 1992, s. 9.

${ }^{4}$ K. Jasiewicz, Fundacje na ziemiach polskich, ,Tygodnik Powszechny” 1990, nr 23.

5 H. Cioch, Fundacja - Zakład Narodowy imienia Ossolińskich jako fundacja prawa publicznego, „Państwo i Prawo” 2000, nr 4, s. 67.

6 Dz.U. z 1919 r. Nr 15, poz. 215.

7 Przykład Fundacja Kościuszkowska powstała w 1925 roku w USA i Polsce. 
strat majątkowy z przeznaczeniem na konkretny cel; drugi to fundacje tworzone również w drodze aktów ustawowych, lecz z majątków osób fizycznych i za ich wolą (przykładem może być fundacja rodziny Zamoyskich pod nazwą Zakłady Kórnickie). Z nastaniem Polski Ludowej instytucja fundacji przestała być potrzebna omnipotentnemu socjalistycznemu państwu, ingerującemu i przejmującemu w zasadzie każdą dziedzinę życia. Przepisy dekretu z 1919 roku, których moc obowiązującą rozciągnięto jeszcze w 1947 roku na obszar całego kraju, zostały ostatecznie uchylone dekretem z dnia 24 kwietnia 1952 roku o zniesieniu fundacji ${ }^{8}$. Instytucję fundacji przywrócono dopiero w połowie lat osiemdziesiątych jako wspomagającą państwo w jego działalności społeczno-ekonomicznej. Stało się to obowiązującą do dzisiaj ustawą z dnia 6 kwietnia 1984 roku o fundacjach ${ }^{9}$.

\section{Aktualny stan prawny}

Ustawa z dnia 6 kwietnia 1984 roku o fundacjach ${ }^{10}$ w 20 artykułach reguluje podstawowe kwestie dotyczące celów działalności, procesu zakładania i likwidacji, wymogów formalnych, nadzoru merytorycznego, kontroli gospodarki finansowej, kwestii podatkowych i wymogów treściowych statutów fundacji. Ustawa ta jednak nie wprowadza definicji legalnej fundacji ${ }^{11}$. Bez wątpienia fundacja jest osobą prawną typu majątkowego, zakładowego, którego podstawą funkcjonowania jest wyodrębniony majątek przeznaczany $\mathrm{w}$ akcie fundacyjnym na określone przez fundatora/fundatorów cele. Zgodnie $\mathrm{z}$ art. 1 ustawy o fundacjach cele fundacji przewidywane przez fundatora nie mogą być sprzeczne z podstawowymi interesami Rzeczypospolitej Polskiej, muszą mieć charakter społecznie lub gospodarczo użyteczny. Wyliczone w art. 1 obszary działalności fundacji, to jest ochrona zdrowia, rozwój gospodarki i nauki czy oświata i wychowanie, są obszarami jedynie przykładowymi, a samo wyliczenie obszarów ma charakter otwarty. W myśl art. 2 ust. 1 fundacje mogą być ustanawiane zarówno przez osoby fizyczne, jak i prawne bez względu na pochodzenie, z zastrzeżeniem ust. 2, że siedziba fundacji powinna znajdować się na terytorium Rzeczypospolitej Polskiej. Fundację ustanawia się $\mathrm{w}$ akcie fundacyjnym, który jest sporządzany w formie aktu notarialnego (art. 3 ust. 1 ustawy o fundacjach), wyjątkiem jest powoływanie fundacji w testamencie (art. 3 ust. 2 ustawy). Oprócz ustawowej podstawy prawnej każda fundacja działa w oparciu o statut, który w myśl art. 5 ust. 1 ustala fundator, określając jej nazwę, siedzibę i majątek, cele, zasady, formy i zakres działalności, skład i organizację zarządu, sposób powoływania oraz obowiązki i uprawnienia tego organu i jego członków. Statut może zawierać również inne postanowienia, w szczególności do-

\footnotetext{
8 Dz.U. z 1952 r. Nr 25, poz. 172.

9 Dz.U. z 1984 r. Nr 21, poz. 97.

10 Tekst jedn. Dz.U. z 2016 r., poz. 40.

11 J. Blicharz, Fundacje wybrane zagadnienia, Wrocław 2016, s. 25.
} 
tyczące prowadzenia przez fundację działalności gospodarczej, dopuszczalności i warunków jej połączenia z inną fundacją, zmiany celu lub statutu, a także przewidywać tworzenie oprócz zarządu innych organów fundacji. Fundacja w ramach swojej działalności podstawowej może prowadzić działalność gospodarczą (art. 5 ust. 5 ustawy o fundacjach), która musi być prowadzona w rozmiarach służących realizacji jej celów. Fundacja podlega obowiązkowi wpisu do krajowego rejestru sądowego i nabywa osobowość prawną oraz możliwość działania, dopiero w momencie wpisu (art. 7 ustawy o fundacjach). Ustawa o fundacjach w dalszych postanowieniach reguluje uprawnienia kontrolne starosty, właściwego ministra ze względu na obszar działalności fundacji, kwestie zwolnień podatkowych, procesu likwidacji fundacji i możliwości działalności przedstawicielstw fundacji zagranicznych.

\section{Fundacja a stowarzyszenie}

Stowarzyszenia działają na podstawie ustawy z dnia 7 kwietnia 1989 roku Prawo o stowarzyszeniach ${ }^{12}$. Jest to regulacja bardziej rozbudowana, pomieszczona w 7 rozdziałach i 57 artykułach. Zaczynając od różnic, od razu trzeba jasno zaznaczyć, że oba podmioty są osobami prawnymi, ale funkcjonującymi na odrębnych „fundamentach”. Podstawą działania fundacji jest majątek przekazywany przez fundatora, na z góry określone cele, jest to więc osoba prawna typu majątkowego, zakładowego ${ }^{13}$. Stowarzyszenia zaś są osobami prawnymi typu zrzeszeniowego. Jak możemy przeczytać w komentarzu do Prawa o stowarzyszeniach autorstwa Pawła Sarneckiego ,w rozumieniu Konstytucji RP z 2 kwietnia 1997 r. stowarzyszenia są jedną z postaci »dobrowolnych zrzeszeń obywateli« (art. 12 Konstytucji) — obok partii politycznych, związków zawodowych, organizacji społeczno-zawodowych rolników, ruchów obywatelskich i fundacji — realizujących również i w tej formie zagwarantowaną konstytucyjnie wolność zrzeszania się (art. 58 Konstytucji)"14. Akcentowana jest więc dobrowolność przynależności do stowarzyszenia. W stowarzyszeniach jako osobach prawnych typu zrzeszeniowego, korporacyjnego występują więc członkowie (art. 2 ust. 3 ustawy prawo o stowarzyszeniach) — w fundacjach członkowie nie występują. Idąc dalej, w momencie zakładania obu podmiotów uwidaczniają się różnice. Fundacja jest tworzona w drodze aktu fundacyjnego, jednego bądź wielu fundatorów, a ustawa o fundacjach nie przewiduje żadnych limitów w tej materii. Jeśli chodzi o stowarzyszenia ustawodawca reguluje to precyzyjniej, gdyż w myśl art. 9 minimalna liczba członków stowarzyszenia to 7 osób. Istotne różnice między porównywanymi podmiotami występują w kwestii władz, gdyż w myśl ustawy o fundacjach jedynym obligatoryjnym organem fundacji jest jej zarząd, inne są fakultatywne,

\footnotetext{
12 Tekst jedn. Dz.U. z 2017 r., poz. 220.

13 H. Cioch, A. Kidyba, Ustawa o fundacjach - komentarz, Warszawa 2007, s. 17.

14 P. Sarnecki, Prawo o stowarzyszeniach — komentarz, Warszawa 2007, s. 3.
} 
zależnie od woli fundatora. Odnosząc się do władz stowarzyszeń, Prawo o stowarzyszeniach przewiduje w art. 11 ust. 1, że najwyższą władzą stowarzyszenia jest walne zebranie członków z przypisanym domniemaniem kompetencji niezastrzeżonych przez statut innym organom. Ponadto ust. 3 art. 11 Prawa o stowarzyszeniach obliguje je do powołania zarządu i organu kontroli wewnętrznej, czego przy fundacjach ustawodawca nie przewiduje. Jeśli chodzi o podobieństwa regulacje prawne dotyczące zarówno fundacji, jak i stowarzyszeń przewidują obowiązek wpisu do krajowego rejestru sądowego (art. 7 ustawy o fundacjach, art. 8 ust. 1 Prawa o stowarzyszeniach). Ponadto oba podmioty korzystają ze zwolnień podatkowych przewidzianych w ustawie o podatku dochodowym od osób prawnych ${ }^{15}$ oraz są zobowiązane do składania sprawozdań finansowych urzędom skarbowym, a fundacje — oprócz tego — właściwym ministrom wskazanym jako organy nadzoru. Fundacje i stowarzyszenia mogą prowadzić działalność gospodarczą, adekwatną do rozmiarów działalności, a członkowie władz nie mogą czerpać korzyści osobistych płynących z owej działalności, dochody z niej płynące muszą być wydatkowane na realizację założonych przez statuty celów (art. 5 ust. 5 ustawy o fundacjach, art. 34 prawa o stowarzyszeniach).

\section{Działalność gospodarcza fundacji}

O możliwości podejmowania i prowadzenia działalności gospodarczej przez fundację stanowi art. 5 ust. 5 ustawy o fundacjach. Jak wskazuje się w literaturze poświęconej fundacjom, może się to odbywać pod następującymi warunkami:

1. należy określić w statucie postanowienia dotyczące prowadzenia działalności gospodarczej;

2. należy przeznaczyć środki majątkowe w wysokości co najmniej 1000 zł na prowadzenie owej działalności. Jest to, jak się wydaje, suma raczej symboliczna w dzisiejszych realiach podejmowania i prowadzenia działalności gospodarczej;

3. ponadto należy prowadzić działalność gospodarczą w rozmiarach odpowiednich do realizacji celów statutowych, co oznacza, że dochody, które owa działalność ma przynosić, muszą być wydatkowane jedynie na cele przewidywane przez statut fundacji;

4. fundacja podejmująca działalność gospodarczą musi zostać wpisana do rejestru przedsiębiorców Krajowego Rejestru Sądowego ${ }^{16}$.

Definiując pojęcie działalności gospodarczej, należy się odnieść do ustawy z dnia 6 marca 2018 roku Prawo przedsiębiorców ${ }^{17}$. W myśl art. 3 działalnością gospodarczą jest zorganizowana działalność zarobkowa wykonywana we własnym imieniu i w sposób ciągły. Podstawowymi przesłankami konstytutywnymi

\footnotetext{
15 Tekst jedn. Dz.U. z 2017 r., poz. 2343.

16 Por. H. Cioch, A. Kidyba, op. cit., s. 40.

17 Dz.U. z 2018 r., poz. 646.
} 
działalności gospodarczej są zatem zarobkowy charakter, jej zorganizowanie, ciągłość oraz działanie we własnym imieniu. Odnosząc się do powyższych cech charakterystycznych, rozumienie definicji charakteru zarobkowego działalności gospodarczej nie zmieniło się $\mathrm{w}$ toku ostatnich zmian regulacji prawnych i oznacza zamiar osiągania zysku z tytułu jej prowadzenia, gdzie zyskiem będzie nadwyżka dochodów nad stratami ${ }^{18}$. Nie jest istotne, czy zysk jest w rzeczywistości osiągany, liczy się subiektywny zamiar jego osiągnięcia ${ }^{19}$. Zorganizowanie działalności polega natomiast na wyborze odpowiedniej formy prawnej, a także tworzeniu przez wykonującego działalność struktur potrzebnych do jej wykonywania ${ }^{20}$. Ciągłość działalności gospodarczej polega na powtarzalności czynności związanych z prowadzoną działalnością, takich samych bądź rodzajowo podobnych ${ }^{21}$. Działalność gospodarcza musi być również wykonywana stale, a nie okazjonalnie; musi być wykonywana we własnym imieniu i na własny rachunek, co oznacza według C. Kosikowskiego odpowiedzialność za wyniki finansowe działalności oraz za zobowiązania natury zarówno publicznej, jak i prywatnoprawnej ${ }^{22}$. Zatem nie stanowi działalności gospodarczej, działalności pracowników, pełnomocników i prokurentów, członków organów osoby prawnej, osób prowadzących administrację masy majątkowej w imieniu jej właściciela ${ }^{23}$. Warto wspomnieć o dwóch istotnych dla fundacji pojęciach - działalności odpłatnej i nieodpłatnej. Ich legalne definicje są zawarte $\mathrm{w}$ ustawie z dnia 24 kwietnia 2003 roku o działalności pożytku publicznego i wolontariacie ${ }^{24}$. W myśl art. 7 ustawy działalnością nieodpłatną pożytku publicznego jest działalność prowadzona przez organizacje pozarządowe i podmioty wymienione w art. 3 ust. 3, w sferze zadań publicznych, o której mowa $\mathrm{w}$ art. 4, za które nie pobierają one wynagrodzenia. Według J. Blicharz takimi działaniami będą przede wszystkim usługi wykonywane na podstawie stosunku prawnego, na przykład poradnictwo prawne wykonywane bez pobierania żadnych opłat $^{25}$. Działalnością odpłatną w myśl art. 8 ustawy o działalności pożytku pub-

18 M. Sieradzka, M. Zdyb, Ustawa o swobodzie działalności gospodarczej. Komentarz, Warszawa 2013, s. 16; Sejm RP 2017, Rządowy projekt ustawy - Prawo przedsiębiorców, uzasadnienie, druk nr 2051, s. 20.

19 Tak wyrok NSA z dnia 26 września 2008 roku, II FSK 789/07, LEX nr 495147, wydany na podstawie nieobowiązującej już ustawy z dnia 2 lipca 2004 roku o swobodzie działalności gospodarczej (tekst jedn. Dz.U. z 2016 r., poz. 1829), jednak zachował aktualność pod rządami obecnej ustawy Prawo przedsiębiorców.

20 H. Cioch, A. Kidyba, op. cit., s. 53.

21 W. Kubala, Prawo działalności gospodarczej, komentarz, Warszawa 2000, s. 46.

22 C. Kosikowski, Ustawa o swobodzie działalności gospodarczej. Komentarz, Warszawa 2005, s. 39.

23 Sejm RP 2017, Rzadowy projekt ustawy..., s. 20-21.

24 Tekst jedn. Dz.U. z 2018 r., poz. 450.

25 J. Blicharz, Komentarz do ustawy o działalności pożytku publicznego i wolontariacie, [w:] Ustawa o działalności pożytku publicznego i wolontariacie. Ustawa o spótdzielniach socjalnych. Komentarz, Warszawa 2012, s. 36. 
licznego będzie działalność wyżej wymienionych podmiotów w sferze zadań publicznych z art. 4, a także sprzedaż wytworzonych towarów lub świadczenie usług w zakresie rehabilitacji społecznej i zawodowej osób niepełnosprawnych na zasadach określonych w ustawie z dnia 27 sierpnia 1997 roku o rehabilitacji zawodowej i społecznej oraz zatrudnianiu osób niepełnosprawnych ${ }^{26}$, a także przez osoby zagrożone wykluczeniem społecznym, o których mowa w ustawie z dnia 13 czerwca 2003 roku o zatrudnieniu socjalnym ${ }^{27}$ i w ustawie $\mathrm{z}$ dnia 27 kwietnia 2006 roku o spółdzielniach socjalnych ${ }^{28}$, za które podmioty te pobierają wynagrodzenie. Co istotne, aby działalność odpłatna nie została zakwalifikowana jako działalność gospodarcza, opłata nie może przewyższać kosztów wytworzenia danych produktów czy świadczenia danych usług (art. 9 ustawy o działalności).

\section{Aspekty praktyczne i problemy w działalności młodych fundacji na przykładzie doświadczeń autora}

Od czterech lat autor jest członkiem zarządu fundacji założonej przez grono absolwentów i nauczycieli Dolnośląskiego Specjalnego Ośrodka Szkolno-Wychowawczego nr 13 dla Dzieci Niewidomych i Słabowidzących im. Marii Grzegorzewskiej. Pomysł założenia fundacji narodził się wiosną 2014 roku. Akt fundacyjny sporządzono w czerwcu 2014 roku i niezwłocznie złożono wniosek o rejestrację do Krajowego Rejestru Sądowego. W myśl art. 20a ust. 1 ustawy z dnia 20 sierpnia 1997 roku o Krajowym Rejestrze Sądowym ${ }^{29}$ wniosek o wpis do rejestru sąd rejestrowy rozpoznaje nie później niż w terminie siedmiu dni od daty jego wpływu. W przypadku konieczności uzupełnienia wniosku przez wnioskodawców, wpis powinien być dokonany w ciągu siedmiu dni od uzupełnienia wniosku (art. 20a ust. 3 ustawy). W praktyce czas oczekiwania na wpis do rejestru wyniósł cztery miesiące. Terminy ustawowe dzięki brzmieniu „wniosek powinien...” uznawane są za terminy instrukcyjne, co powoduje, że za ich przekroczenie ustawodawca nie przewiduje żadnych sankcji. Fundacje po zarejestrowaniu w KRS mają coraz większe problemy z rozpoczęciem realizacji celów statutowych. Na przykładzie fundacji, w której władzach autor zasiada, można stwierdzić, że w konkursach o finansowanie realizacji zadań ze sfery zadań publicznych na rzecz osób niepełnosprawnych, ogłaszanych przez organy władzy publicznej, są dopuszczane wszystkie podmioty spełniające warunki, ale kryteria rozpatrywania aplikacji uczestników konkursu są mało przejrzyste. Niektóre odpowiedzi uzyskiwane od organów rozpisujących konkursy stanowiły, że wnioski o dotację dla fundacji uzyskiwały maksymalne oceny pod względem merytorycznym, co jednak nie powo-

\footnotetext{
26 Tekst jedn. Dz.U. z 2018 r., poz. 511.

27 Tekst jedn. Dz.U. z 2016 r., poz. 1828.

28 Dz.U. z 2006 r. Nr 94, poz. 651 z późn. zm.

29 Tekst jedn. Dz.U. z 2018 r., poz. 986.
} 
dowało przyznania dotacji. Brak doświadczenia i udokumentowanej historii projektowej jest przypuszczalnie przeszkodą pozamerytoryczną dla organów władzy publicznej. Rodzi się pytanie, gdzie należy zdobyć doświadczenie. Wychodząc poza aspekty prawne, należy podkreślić, że w w zarządzie każdej fundacji, mimo zakładanego kolektywnego działania władz, musi być silny lider. Istotna jest też dobra współpraca członków zarządu, a także jasno sprecyzowane cele działalności. Start dla młodych fundacji - czyli pierwsze dwa lata działalności, przed możliwością uzyskania statusu organizacji pożytku publicznego (art. 22 ust. 1 ustawy o działalności) — jest coraz trudniejszy również dlatego, że z kolejnymi perspektywami finansowymi Unii Europejskiej zmniejszają się środki pomocowe dla trzeciego sektora. Z opinii środowiska organizacji pozarządowych wynika, że najkorzystniejszym okresem funkcjonowania było pierwsze kilka lat po akcesji Polski do struktur UE. Status OPP pozwala organizacjom pozarządowym, w tym fundacjom, na pozyskiwanie środków finansowych od osób fizycznych poprzez fakultatywną możliwość przekazania $1 \%$ należnego podatku dochodowego (art. 27 ust. 1 ustawy o działalności pożytku publicznego i wolontariacie).

\section{Obszary działań fundacji pomagających osobom z niepełnosprawnością i starszym}

Zgodnie z danymi portalu organizacji pozarządowych na początku roku 2018 w Polsce było zarejestrowanych ponad 22 tys. fundacji, z czego według szacunków Stowarzyszenia Klon/Jawor na podstawie wyników badań „Kondycja sektora organizacji pozarządowych" około $70 \%$ z nich prowadziło aktywną działalność ${ }^{30}$. Najczęstszym obszarem aktywności fundacji pomagających osobom starszym jest pomoc w opiece nad seniorami, czego przyczynę stanowi szybko powiększająca się ich liczba. Często te same fundacje mają w swoich statutach zapisane i prowadzą swoje działania zarówno w obszarach pomocy senioralnej, jak i pomocy osobom niepełnosprawnym. Doświadczenia autora potwierdzają tę tezę. W roku 2014 autor korzystał z pomocy asystenckiej prowadzonej przez fundację Spokojna Jesień z Sobótki, której podstawowymi celami były opieka nad osobami starszymi, a także przeciwdziałanie dyskryminacji seniorów ze względu na wiek. Pomoc osobom niepełnosprawnym, ich aktywizacja również była celem statutowym fundacji ${ }^{31}$. Innymi obszarami aktywności fundacji senioralnych są: ułatwianie dostępu do dóbr kultury i sztuki, a także propagowanie turystyki ${ }^{32}$. Odnosząc się do ułatwień dostępu do kultury i sztuki, autor ma doświadczenia w tej dziedzinie, gdyż przez rok uczęszczał na comiesięczne pokazy filmów z audiodeskrypcją

30 Portal www.ngo.pl — portal organizacji pozarządowych, http://fakty.ngo.pl/wiadomosc/ 2174099.html (dostęp: 29.05.2018).

31 Fundacja Spokojna jesień, http://www.spokojnajesien.org (dostęp: 15.02.2017).

32 W sferze turystyki przykład Fundacja Teraz Senior, www.terazsenior.pl (dostęp: 29.05.2018). 
organizowane w kinie Nowe Horyzonty, w których uczestniczyło wielu niewidomych i niedowidzących seniorów zapraszanych przez wiele fundacji. Ważnym obszarem aktywności dla fundacji działających na rzecz seniorów są licznie powstające i prężnie działające uniwersytety trzeciego wieku. Poza uniwersytetami działającymi przy uczelniach wyższych, jako ich jednostki organizacyjne, i tych działających przy miejskich ośrodkach pomocy społecznej i domach kultury również fundacje są uznaną formą działalności w obszarze kształcenia seniorów ${ }^{33}$.

Nie ma specjalnych regulacji prawnych dla opisywanej formy działalności senioralnej, a w przypadku fundacji zastosowanie będą miały wszystkie omawiane powyżej regulacje. Na koniec warto nadmienić, że dla samych seniorów angażowanie się w działalność społeczną stanowi możliwość wykorzystania wolnego czasu i utrzymania sprawności umysłowej.

\section{Podsumowanie}

W powyższym artykule autor podjął próbę ukazania konstrukcji prawnej, aspektów praktycznych i obszarów aktywności fundacji działających na rzecz seniorów i osób niepełnosprawnych. Wskazano zalety fundacji w zestawieniu z konstrukcją prawną stowarzyszeń. Należy wyraźnie zaznaczyć, że fundacje jako osoby prawne typu zakładowego są łatwiejsze w zarządzaniu, kierowaniu i prowadzeniu działalności na rzecz zewnętrznych beneficjentów niż stowarzyszenia, które mogą dodatkowo działać na rzecz swoich członków. Opisanie pojęcia działalności gospodarczej, którą fundacje mogą prowadzić akcesoryjnie do swojej głównej działalności, miało na celu uściślenie kwestii, jaka działalność jest gospodarczą, a jaka nie (działalność nieodpłatna i działalność odpłatna pod pewnymi warunkami działalnością gospodarczą nie są). Należy zauważyć, że doświadczenia autora w zarządzaniu fundacją nie są jednoznacznie pozytywne — zarówno od strony organów administracji publicznej, jak i od strony fundacji jest wiele niedociągnięć. Procedury rejestracyjne i nieprzejrzyste zasady konkursów nie wpłynęły pozytywnie na początkowy etap działalności, co spowodowało osłabienie woli członków władz fundacji do dalszego działania. W sferze działalności senioralnej oraz aktywizacji osób starszych wyraźnie widać, że fundacje działają głównie w obszarze opieki nad osobami starszymi. Pozytywny jest trend rozszerzania obszarów działania podmiotów trzeciego sektora na obszary kultury i sztuki czy turystyki senioralnej. W opinii autora seniorzy mają duży potencjał do zakładania lub działania w podmiotach z obszaru trzeciego sektora, dodatkowo bardzo pozytywne jest działalność uniwersytetów trzeciego wieku. Kończąc rozważania, łatwo zauważyć, że forma prawna fundacji to dobry sposób

33 Strona Uniwersytetu Trzeciego Wieku Uniwersytetu Jagiellońskiego, http://www.utw.uj.edu. pl/ (dostęp: 31.05.2018). 
na działalność na rzecz seniorów i osób niepełnosprawnych. Dodatkowo autor uważa, że forma ta jest korzystna dla seniorów jako przedłużenie ich aktywności zawodowej i społecznej.

\section{Bibliografia* $^{*}$}

Blicharz J., Fundacje wybrane zagadnienia, Wrocław 2016.

Blicharz J., Komentarz do ustawy o działalności pożytku publicznego i wolontariacie, [w:] Ustawa o działalności pożytku publicznego i wolontariacie. Ustawa o spółdzielniach socjalnych. Komentarz, Warszawa 2012.

Cioch H., Fundacja - Zaklad Narodowy imienia Ossolińskich jako fundacja prawa publicznego, „Państwo i Prawo” 2000, nr 4.

Cioch H. Kidyba A., Ustawa o fundacjach — komentarz, Warszawa 2007.

Izdebski H., Fundacje i stowarzyszenia. Komentarz. Orzecznictwo, Warszawa 2003.

Jasiewicz K., Fundacje na ziemiach polskich, ,Tygodnik Powszechny” 1990, nr 23.

Kolańczyk K., Prawo rzymskie, Warszawa 2000.

Kosikowski C., Ustawa o swobodzie działalności gospodarczej. Komentarz, Warszawa 2005.

Kubala W., Prawo działalności gospodarczej. Komentarz, Warszawa 2000.

Niemirka B., Statut fundacji, Warszawa 1995.

Sagan B. Strzępka J., Prawo o fundacjach. Komentarz, Katowice 1992.

Sarnecki P., Prawo o stowarzyszeniach - komentarz, Warszawa 2007.

Sieradzka M., Zdyb M., Ustawa o swobodzie działalności gospodarczej. Komentarz, Warszawa 2013.

\section{Akty prawne}

Sejm RP, Rządowy projekt ustawy - Prawo przedsiębiorców, uzasadnienie, druk nr 2051, Warszawa 2017.

Ustawa z dnia 6 kwietnia 1984 roku o fundacjach (tekst jedn. Dz.U. z 2016 r. Nr 40).

Ustawa z dnia 7 kwietnia 1989 roku Prawo o stowarzyszeniach (tekst jedn. Dz.U. z 2017 r., poz. 220).

Ustawa z dnia 15 lutego 1992 roku o podatku dochodowym od osób prawnych (tekst jedn. Dz.U. z 2017 r., poz. 2343).

Ustawa z dnia 20 sierpnia 1997 roku o krajowym rejestrze sądowym (tekst jedn. Dz.U. z 2018 r., poz. 986).

Ustawa z dnia 27 sierpnia 1997 roku o rehabilitacji zawodowej i społecznej oraz zatrudnianiu osób niepełnosprawnych (tekst jedn. Dz.U. z 2018 r., poz. 511).

Ustawa z dnia 2 lipca 2004 roku o swobodzie działalności gospodarczej (tekst jedn. Dz.U. z 2016 r. $\mathrm{Nr} 1829$ ).

Ustawa z dnia 24 kwietnia 2003 roku o działalności pożytku publicznego i wolontariacie (tekst jedn. Dz.U. z 2018 r., poz. 450).

Ustawa z dnia 13 czerwca 2003 roku o zatrudnieniu socjalnym (tekst jedn. Dz.U. z 2016 r., poz. 1828).

Ustawa z dnia 27 kwietnia 2006 roku o spółdzielniach socjalnych (Dz.U. z 2006 r. Nr 94, poz. 651 z późn. zm.).

Ustawa z dnia 6 marca 2018 roku Prawo przedsiębiorców (Dz.U. z 2018 r., poz. 646).

* Informuję, że ze względu na moją niepełnosprawność wzrokową użyta do napisania niniejszego artykułu literatura dostępna mi była w formie elektronicznej. $Z$ tego powodu numeracja stron może się różnić od numeracji w wersjach papierowych wykorzystanych pozycji. 


\section{Orzecznictwo}

Dekret Naczelnika Państwa z dnia 7 lutego 1919 roku o fundacjach i zatwierdzaniu darowizn i zapisów. (Dz.U. z 1919 r. Nr 15, poz. 215).

Dekret Rady Ministrów z dnia 24 kwietnia 1952 r. o zniesieniu fundacji (Dz.U. z 1952 r. Nr 25, poz. 172).

Wyrok NSA z dnia 26 września 2008 r., II FSK 789/07, LEX nr 495147).

\section{Źródła internetowe}

Portal organizacji pozarządowych, www.ngo.pl

Strona Drzewo oliwne dawniej Fundacja Spokojna jesień http://www.spokojnajesien.org

Strona fundacji Teraz Senior www.terazsenior.pl

Strona Uniwersytetu Trzeciego Wieku Uniwersytetu Jagiellońskiego, http://www.utw.uj.edu.pl

\section{The foundation as the form activation of the of disabled and elderly persons}

\section{Summary}

In the above article I tried to portray legal construction, practical aspects and scope of foundations' activities for senior and disabled people. I also tried to show advantages of the foundation in comparison with the legal construction of associations. It is necessary to clearly state here that foundations, as based on their assets, are easier to manage and direct activities to outside beneficiaries than associations which can also act for their members only. Economic activity that foundations can perform must be of accessory character and must relate to and support financially the foundation's main activity.

My experience while working at the foundation is not explicitly positive. Long lasting registration procedures and opaque principles of competitions certainly did not have a positive effect on the initial stage of its activity.

Foundations operate mainly in the area of the care of elderly people. A positive trend is however observed in the areas of culture, art or tourism amongst the elderly. I also believe that seniors have great potential for establishing or operating in such units of the third sector.The development and functioning of Universities of the Third Age is worth appreciating. 